\title{
EFFECT OF BLACK RASPBERRY ON NF-KB AND CASPASE-3 EXPRESSION IN HEAD AND NECK SQUAMOUS CELL CARCINOMA VERSUS KERATINOCYTES AND FIBROBLASTS CELL LINES
}

\author{
Shaimaa Eliwa Ghazy* and Dina Hazem Hassan Gomaa**
}

\begin{abstract}
Review: Oral squamous cell carcinoma (OSCC), the most common type of intraoral cancers, is an important health issue. Most cytotoxic drugs have side effects on normal tissues beside being cytotoxic to malignant cells. Many studies demonstrated the ability of black raspberries (BRBs) to inhibit many types of cancer. However, understanding how the bioactive compounds in BRBs drive the metabolic and molecular pathways that lead to oral cancer chemoprevention remains unclear.
\end{abstract}

Aim of study: The current study aimed to investigate the consequences of BRBs treatment on $(\mathrm{NF}-\mathrm{KB})$ and caspase-3 expression in two types of head and neck SCC cell lines in comparison to both normal keratinocyte and fibroblast cell lines.

Results: There was an inhibitory effect of BRBs on both tested malignant cell lines (SCC9), and (HEp-2) and at the same time there was no effect on growth of the tested normal cell lines $(\mathrm{HaCaT})$ and $(\mathrm{BJ})$. There was a statistically significant increase in median fold change of caspase-3 in the tested malignant cell lines and a statistically significant decrease in the median fold change of NF- $x \mathrm{~B}$ in the tested malignant cells with no detectable change for both antigens in the normal cell lines.

Conclusion: The results of the present study provide more evidence that BRBs have a very promising cytotoxic effect on oral cancer cell lines with no detectable harmful effect on normal cells.

KEY WARDS: Squamous cell carcinoma cell line, Caspase-3, NF- $\varkappa$ B, Black raspberry.

\section{INTRODUCTION}

Oral squamous cell carcinoma (OSCC), the most common type of intraoral cancers, is an important health issue. OSCC is a serious locally invading tumour, which may invade the soft tissue and bone, and can spread to nerves, lymphatics and blood vessels. So it can spread and give rise to cervical lymph nodes metastasis and distant metastasis. Moreover, regardless the great attempts to upgrade

* Lecturer of Oral Pathology, Faculty of Dentistry, Ain Shams University.

** Lecturer of Oral Biology, Faculty of Dentistry, Ain Shams University. 
anti-cancer drugs, the cure rates for late-stage oral SCC remain frustrating. ${ }^{(1,2,3)}$

Most cytotoxic drugs have side effects on normal tissues beside being cytotoxic to malignant cells. Destruction of proliferating normal cells is considered one of the obstacles that limits chemotherapy of cancer. For example among the most important cytotoxic drugs is doxorubicin which shows severe cytotoxic effect against human normal oral keratinocytes, also 5-Flourouracil drug stimulates ROS production which give rise to oral mucositis. So the last few decades showed increased attention on the natural herbs or plants, because of their limited complications and little side effects compared to ordinary chemotherapy. ${ }^{(4,5,6,7)}$

Many studies demonstrated the ability of black raspberries (BRBs) to inhibit many types of cancer. However, understanding how the bioactive compounds in BRBs drive the metabolic and molecular pathways that lead to oral cancer chemoprevention remains unclear. ${ }^{(8)}$

The bioactive phytochemicals in BRBs are classified according to structure and chemical category into phenolic acids, flavonoids (anthocyanins, flavanols), condensed tannins (proanthocyanins), hydrolyzable tannins (ellagitannins and gallotannins), stilbenoids, lignans, , sterols. $\beta$-sitosterol, ferulic acid and quercitin. The antioxidant effect of BRBs is caused mainly by anthocyanins and ellagitannins fractions. ${ }^{(9,10)}$

Besides the previous components, BRBs contain many other constituents known to exert cancerprotective effect like vitamins A, C, E, folic acid, calcium and zinc. The anti-cancer effect of these constituents is attributed to their antioxidant power. ${ }^{(11)}$

BRBs bioactives have several functions in cancer protection not only treatment. Among these functions, the defence against DNA deterioration by the elimination of reactive oxygen species, suppression of DNA damage induced by chemical carcinogens and alterations of expression of cellular molecules involved in cellular growth, angiogenesis and programmed cell death. ${ }^{(12)}$

Abnormal apoptosis has a major role in the development of malignancy. Evasion from apoptosis might be one of the main mechanisms by which malignant tumours fight the usual chemotherapeutic protocols. ${ }^{(13)}$

Apoptosis is stimulated by activation of caspases protein family through two different pathways known as intrinsic and extrinsic pathways. Caspases are classified into: initiator caspases (caspase-2, $-8,-9$ and -10) and effector caspases (caspase-3, -6 and 7), they act on many cellular proteins , finally ending up with cell death. Because of the low amount of tissue destruction associated with apoptosis, it is considered one of the main strategies of anti-cancer treatment. ${ }^{(14,15,16)}$

The transcription factor nuclear factor- $x \mathrm{~B}$ $(\mathrm{NF}-\kappa \mathrm{B})$ regulates the expression of different genes which are implicated in immune and inflammatory reactions, proliferation, cancer development and cell survival. Several studies proved that NF- $\kappa \mathrm{B}$ signalling pathway contributes to cancer development and it is responsible for increased invasion, survival, chemoresistance, and angiogenesis in a number of cancer types, including OSCC . As a result, NF- $\mathrm{KB}$ is considered as an influential anti malignant target. ${ }^{(17,18,19,20)}$

To our knowledge a few studies have been conducted to investigate the possible effect of (BRBs) on both oral malignant and normal cells. So the current study aimed to investigate consequences of BRBs treatment on (NF- $\kappa \mathrm{B})$ and caspase-3 expression in two types of head and neck SCC cell lines in comparison to both normal keratinocyte and fibroblast cell lines. 


\section{MATERIALS AND METHODS}

Cell lines: SCC 9, HEp-2,HaCaT (keratinocytes) and BJ (fibroblasts) cell lines of the American Type Culture Collection (ATCC) ${ }^{\circledR}$ were obtained from VACSERA-EGYPT. The cells were grown in DMEM containing 10\% fetal bovine serum, 10 $\mathrm{ug} / \mathrm{ml}$ of insulin and $1 \%$ penicillin-streptomycin at $37^{\circ} \mathrm{C}$. All of the chemicals and reagents were from Invitrogen.

Black raspberry: Freezed dried whole black raspberry extract powder was purchased from (BerriHealth, Corvallis, OR, USA) ®.

\section{Cell Proliferation Assay (MTT Assay)}

The viability of the tested cell lines was established using the MTT (3-[4,5-dimethylthiazol2yl]-2.5-diphenyl tetrazolium bromide) in vitro toxicology assay kit, MTT based, Stock No. TOX1 (Trevigen SIGMA, Saint Louis, Missouri, USA) as per manufacturer's recommendations. In brief, cells were added in a 96-well tissue culture plates in a range of 103-105 cells/well in a $100 \mathrm{uL}$ of the culture medium then were left overnight. The MTT reagent was applied (10 ul / well) then the cells were incubated for $12 \mathrm{~h}$ to promote the formation of insoluble purple formazan dye. The formazan dye was dissolved before evaluation of the absorbance of each cell line in a ROBONIK P2000 Spectrophotometer, wave length:450-560 $\mathrm{nm}$. Using the MTT assay, the IC50 (Inhibition Cellular Proliferation by 50\%) of black raspberry for each group was calculated. The RT-PCR thereafter were performed using the calculated IC50 for 48 hours duration for each cell line.

\section{Real time PCR}

To determine the mRNA levels of Caspase- 3 and NF- $x \mathrm{~B}$ in all tested groups, one-step qRTPCR test was done. The RNA isolation was performed with RNAiso reagent. Onestep qRT-PCR was carried out with Qiagen One Step SYBR ${ }^{\circledR}$ PrimeScript
TM PLUS RT-PCR Kit on StepOne real time PCR machine by $\Delta \Delta \mathrm{Ct}$ method and mRNA level of actin was utilized as endogenous control.

The primers applied to define the mRNA level of Caspase-3 and NF- $\varkappa$ B were purchased from Invitrogen : The base sequences of the two genes were as follows

Caspase-3: CASP3-F 5' -TTC ATT ATT CAG GCC TGC CGA GG-3'

CASP3-R 5'-TTC TGA CAG GCC ATG TCA TCC TCA-3'

NF- $\kappa$ B: NF- $x$ B F 5'- ATGGCTTCTATGAGGCTGAG -3'

NF-кB R, 5' - GTTGTTGTTGGTCTGGATGC -3'

$\beta$-actin: $\quad \beta$-actin $\quad$ F $\quad 5$-GTGACATCCACACCCAGAGG-3'

$\beta$-actin R 5'-ACAGGATGTCAAAACTGCCC-3'

\section{Statistical analysis}

The results were tabulated using Microsoft Excel (Microsoft Office 2007). Every group was included. The results were assessed using the Statistical Package for Social Science (SPSS 15.0) Software. Data were represented as median, range, mean and standard deviation (SD) values. Kruskal-Wallis test was used to compare between the four groups. Dunn's test was applied for pair-wise comparisons when Kruskal-Wallis test is significant. Results were considered significant when $\mathrm{P}$ value $\leq 0.05$.

\section{RESULTS}

\section{Cell Proliferation Assay (MTT Assay)}

MTT assay results showed that the mean IC 50 value in all different tested cell lines (SCC9), (HEp-2), (HaCaT) and (BJ) was 14.6, 18.2 ,105.1 and $144.4 \mathrm{ug} / \mathrm{ml}$ respectively. The (BJ) cells showed the statistically significant highest median IC50 level. Followed by (HaCat) cells which showed the 
second highest IC 50 value. Both (SCC9 and HEp2) cell lines revealed the statistical significant lowest median IC50 levels with no statistical significant difference between them. (Table 1, fig 1)

TABLE (1): Descriptive statistics and results of Kruskal-Wallis test for comparison between IC50 levels in the different groups

\begin{tabular}{llllll}
\hline Group & Median & Range & Mean & SD & $P$-value \\
\hline SCC9 & $14.6^{\text {C }}$ & $14-15.4$ & 14.67 & 0.7 & \\
HEp-2 & $18.2^{\text {C }}$ & $17.5-19.1$ & 18.2 & 0.82 & \\
HaCaT & $105.13^{\text {в }}$ & $100-110.4$ & 105.13 & 5.2 & \\
BJ & $145^{\text {А }}$ & $138-150.4$ & 144.47 & 6.22 & \\
\hline
\end{tabular}

Significant at $P \leq 0.05$

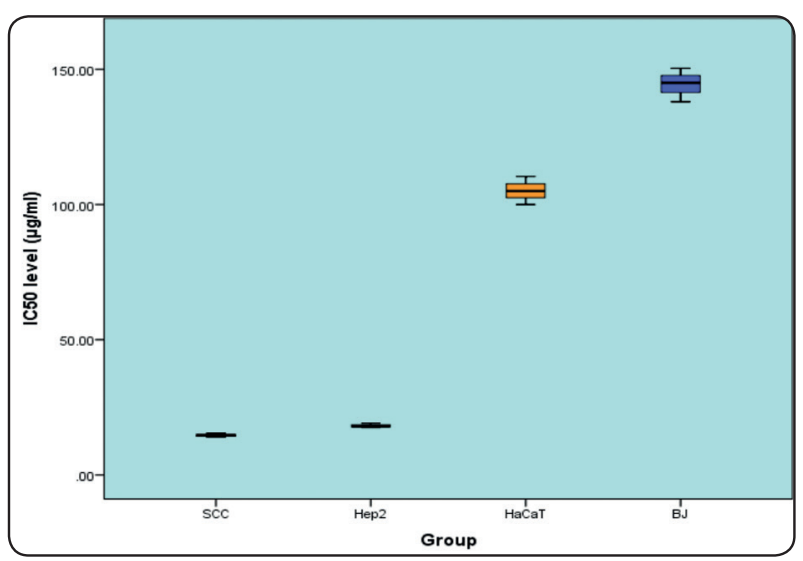

Fig. (1): Box plot representing median and range values for IC50 levels in the different tested groups

\section{Real Time PCR}

The effect of BRBs on the expression of caspase-3 in all tested cell lines (SCC9), (HEp-2), (HaCaT) and ( BJ) is shown in ( table 2), the highest significant expression of median fold change of caspase-3 was observed in (SCC9) cells followed by (HEp-2) cells, with no statistical significant difference between them, while ( $\mathrm{HaCaT}$ and $\mathrm{BJ}$ ) cell lines showed the lowest statistical significant median fold change with also no significant difference between them. ( Table 2,fig 2)

TABLE (2): Descriptive statistics and results of Kruskal-Wallis test for comparison between Caspase- 3 fold changes in the different groups

\begin{tabular}{|c|c|c|c|c|c|}
\hline Group & Median & Range & Mean & SD & $\mathrm{P}$-value \\
\hline SCC9 & $6.73^{\mathrm{A}}$ & $6.53-8.97$ & 7.41 & 1.35 & \multirow{4}{*}{$0.025^{*}$} \\
\hline HEp-2 & $5.45^{\mathrm{A}}$ & $3.09-5.69$ & 4.74 & 1.44 & \\
\hline $\mathrm{HaCaT}$ & $1.18^{\mathrm{B}}$ & $1.15-1.33$ & 1.22 & 0.1 & \\
\hline BJ & $1.18^{\mathrm{B}}$ & $1.12-1.31$ & 1.2 & 0.1 & \\
\hline
\end{tabular}

*: Significant at $P \leq 0.05$

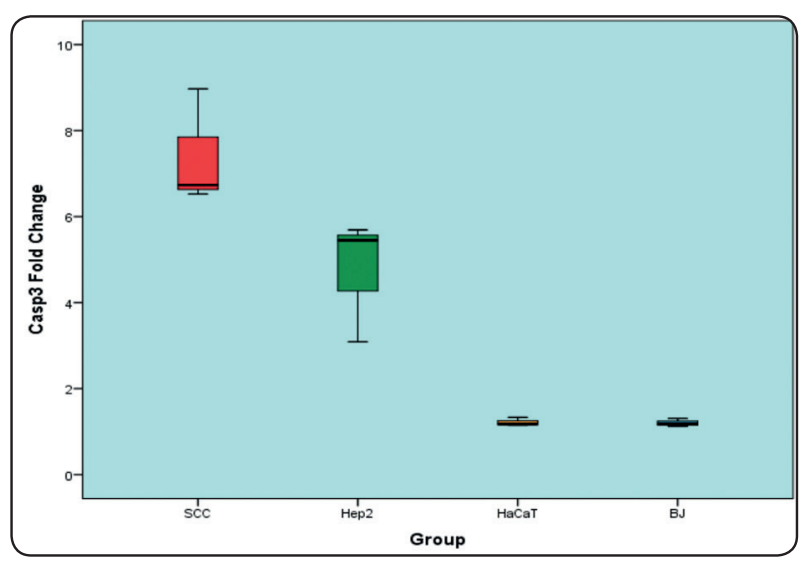

Fig. (2): Box plot representing median and range values for Caspase- 3 fold change in the different tested groups

The effect of BRBs on the expression of NF- $\kappa \mathrm{B}$ in all tested cell lines (SCC9), (HEp-2), $(\mathrm{HaCaT})$ and $(\mathrm{BJ})$ is shown in ( table 3), the lowest significant expression of NF- $\kappa \mathrm{B}$ was observed in (SCC9) cells followed by ( HEp-2) cell line with no statistical significant difference between them. While (HaCaT and $\mathrm{BJ}$ ) cell lines showed the 
statistical significant highest median fold change with also no significant difference between them. ( table 3, fig 3)

TABLE (3): Descriptive statistics and results of Kruskal-Wallis test for comparison between $\mathrm{NF}-\kappa \mathrm{B}$ fold changes in the different groups

\begin{tabular}{cccccc}
\hline Group & Median & Range & Mean & SD & P-value \\
\hline SCC9 & $0.17^{\text {в }}$ & $0.12-0.19$ & 0.16 & 0.04 & \\
HEp-2 & $0.17^{\text {в }}$ & $0.15-0.21$ & 0.17 & 0.03 & \\
HaCaT & $1.03^{\text {А }}$ & $0.99-1.07$ & 1.03 & 0.04 & $0.025^{*}$ \\
BJ & $0.91^{\text {А }}$ & $0.83-0.96$ & 0.9 & 0.07 & \\
\hline
\end{tabular}

*: Significant at $P \leq 0.05$

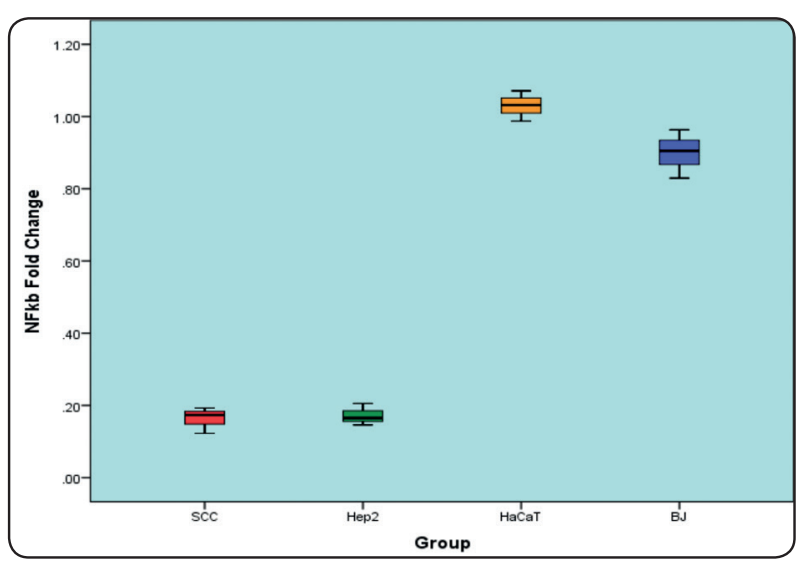

Fig. (3): Box plot representing median and range values for NF$\kappa \mathrm{B}$ fold change in the different tested groups

\section{DISCUSSION}

Many studies revealed that eating much fruits and vegetables reduces the occurrence of cancer. Fruits and vegetables are considered as a main sources of antioxidants, which hugely fight cancer. ${ }^{(9,12,21)}$

Black raspberry is one of the most used types of berries in markets. Between the dominant antioxidant constituent in berries are the anthocyanins and ellagitannins, which play a major role in its anticancer effect. ${ }^{(12,22)}$

Some researchers have examined the BRBs different effects on cancer, such as inhibition of tumour proliferation, angiogenesis and promotion of programmed cell. ${ }^{(12,23)}$ For instance BRBs extracts has been shown to reduce the proliferation of human cervical, oral ,breast, colon and prostate cancer cell lines. ${ }^{(24,25)}$

In this study, we have broadened our recognition of the mechanism of action of BRBs ,by comparing its effect on proliferation and apoptosis on both malignant oral cell lines and normal cells lines.

In the current study, MTT assay revealed inhibitory effect of BRBs on both tested malignant cell lines (SCC9) and (HEp-2), with IC 50 value $14.6,18.2 \mathrm{ug} / \mathrm{ml}$ respectively and at the same time there was no effect on growth of the tested normal cell lines $(\mathrm{HaCaT})$ and $(\mathrm{BJ})$, where the 48-hr neoplastic IC50 dosages were not toxic to the normal cells and the normal cells showed inhibition of proliferation at a very high values of IC50. Han C. et al, 2005, have demonstrated that black raspberries prevent the proliferation of only premalignant and malignant but not normal human cell lines. ${ }^{(26,27)}$ This result is in agreement with our study results that showed the selective inhibition of BRBs on the growth of only cancer cell lines.

Programmed cell death is controlled by caspases family, which induces the release of cytochrome $\mathrm{c}$ and activates many damaging enzymes that digest many vital cellular proteins. . $^{28)}$

Apoptosis is considered one of the main strategies of anti-cancer treatment. So in the present study the effect of BRBs on apoptosis in OSCC was examined. Our results revealed that BRBs extract induced the over expression of caspase-3 in the tested malignant cell lines (SCC9) and (HEp-2) where both showed the highest mean values. While the normal cell lines (HaCaT) and 
(BJ) both showed the lowest statistical significant mean value of caspase-3. This result was in agreement with other previous studies, where BRBs induced selective activation of apoptosis in only highly malignant cells, through stimulation of caspases- 3 and $7 .^{(29,30)}$

The antiapoptotic effect of BRBs may be due to the influence of anthocyanin and Quercetin, through the induction of cell cycle arrest while going through apoptosis with the inhibition of Bcl-2, and the stimulation of the Bak, Bax, cytochrome $\mathrm{c}$ and caspase- 3 expression. ${ }^{(31)}$

$\mathrm{NF}-\kappa \mathrm{B}$ is significantly increased in OSCC and its overexpression induces epitheliummesenchyme transition (EMT) and increases the expression of degradation enzymes, such as matrix metalloproteinase (MMP)-9 indicating that NF- $\kappa B$ may significantly allow progression and metastasis in OSCC. . $^{20,32,33)}$

The present study revealed that BRBs extract induced the inhibition of $\mathrm{NF}-\mathrm{\kappa B}$ expression in the tested malignant cell lines (SCC 9) and (HEp-2 ), where both showed the statistically significant lowest median fold change compared to the control. While the tested normal cell lines showed the statistically significant highest median fold change. Our results were in accordance with previous studies, where $\mathrm{BRBs}$ inhibited the NF- $\mathrm{\kappa B}$ expression in breast cell line (MCF-7) and mouse epidermal cells that were transfected with (NF- $\kappa \mathrm{B})$. Some previous studies mentioned that anthocyanins may be responsible for the inhibition of NF- $\kappa \mathrm{B}$ activity through the prevention of mitogen-activated protein kinase activation and the phosphorylation of the inhibitory subunit $\kappa \mathrm{B}^{(12,34,35)}$

Its worth mentioning here that, the principle for this selectivity of BRBs on only tumour rather than normal cells may be explained by Zikiri et al,2009, findings who clarified that this selectivity may be attributed, partially, to the biased uptake of anthocyanin by only malignant tumours. The mechanism of the preferential uptake and retention of black raspberry anthocyanin is still obscure, but may be linked to the fact that cancer cells are more energetic in pinocytosis state so they could "ingest" extracellular black raspberry more efficiently. Also this selective uptake in particular cells may be a receptor-mediated process. If specific type of cells has more receptors for anthocyanin then other, they will be able to retain more amount of black raspberry anthocyanin by receptor-mediated endocytosis. ${ }^{(29)}$

\section{CONCLUSION}

The results of the present study provide more evidence that BRBs have a very promising selective cytotoxic effect on oral cancer cell lines with no detectable harmful effect on normal cells, this cytotoxic effect was confirmed by the inhibition of $\mathrm{NF}-\kappa \mathrm{B}$ pathway and the activation of caspase-3.

\section{RECOMMENDATIONS}

Future investigations is needed to study the effect of each individual constituent of BRBs on OSCC to find out how strong the effect of each compound when used individually and to compare the results with the effect of whole BRBs extract both in vitro and in animal models.

\section{REFERENCES}

1. Forastiere A.: Head and neck cancer: overview of recent developments and future direction. Semin. Oncol. 2000;27:1- 4 .

2. Olsen S., Moore E., Koch C., Kasperbauer J. and Olsen $\mathrm{K}$.: Oral cavity and oropharynx squamous cell carcinoma with metastasis to the parotid lymph nodes. Oral Oncol. 2011;47: 142-144.

3. Rodrigo, K., Rawal Y., Renner R., Schwartz S., Tian Q., Larsen P.and MalleryS.: Suppression of the Tumorigenic Phenotype in Human Oral Squamous Cell Carcinoma Cells by an Ethanol Extract Derived From Freeze-Dried Black Raspberries. Nutr. Canc. 2006 ;54: 58-68.

4. Apontes P., Leontieva O., Demidenko Z., Li F. and Blagosklonny M.: Exploring long-term protection of normal 
human fibroblasts and epithelial cells from chemotherapy in cell culture. Oncol. Target 2011; 2: $222-233$.

5. Sakagami H., Okudaira N., Masuda Y., Amano O., Yakose S., Kanada Y., Suguro M., Natori T.,Oizumi H. and Oizumi T.:Induction of apoptosis in human oral keratinocytes by Doxorubicin. Anti. Canc. Res.2017:37:1023-1029.

6. Takano H. Momota Y., Kani K., Aota k., Yamamura Y.,Yamanoi T. and Azuma M.: $\gamma$-tocotrienol tocotrienol prevents 5-FU-induced reactive oxygen species production in human oral keratinocytes through the stabilization of 5-FU-induced activation of Nrf2. Intern. J. of Oncol. 2015; 46: 1453-1460.

7. Cragg G., Grothaus, Grothaus P. and Newman D.:Impact of natural products on developing new anti-cancer agents. Chemi. reviews 2009; 109: 3012-3043.

8. Oghumu S., Knobloch T., Weghorst L., Bruschweiler-Li L., Wang C., Bruschweiler R. and Weghorst C.: Potential metabolic and molecular mechanisms of black raspberrymediated oral cancer chemoprevention. AACR 2018; 78; 14-18.

9. Seeram N.: Nutritional Oncolog . Heber,D., Blackburn,G., Go,V. and Milner,J. (eds.). Elsevier, Inc., Amsterdam, the Netherlands, 2006,pp. 615-628 Chapter 37.

10. Wada,L. and Ou B.:Antioxidant activity and phenolic content of Oregon caneberries. J. Agric. Food Chem.2002; 50: 3495-3500.

11. Kresly L., Morse M., Morgan C., Carlton P., Lu J., Gupta A., Blackwood M. and Stoner G.: Chemoprevention of esophageal tumorigenesis by dietary administration of lyophilized black raspberries. Canc. Res. 2001;61: 61126119 .

12. Stoner G., Wang L. and Casto1 B.: Laboratory and clinical studies of cancer chemoprevention by antioxidants in berries. Carcinogenesis 2008;29:1665-1674.

13. Kasibhatla S. and Maxim B.: Why Target Apoptosis in Cancer Treatment?. Mol. Canc. Therapeut. 2003;2: 573580 .

14. Adams J.: Ways of dying: multiple pathways to apoptosis. Genes Dev. 2003; 17: 2481-2495.

15. Olsson M. and Zhivotovsky B.: Caspases and cancer. Cell Death and Differen. 2011; 1:1441-1449.

16. Baig S., Seevasant I., Mohamad J., Mukheem A., Huri H. and Kamarul T.: Potential of apoptotic pathway-targeted cancer therapeutic research: Where do we stand?. Cell Death Dis. 2016;7:e2058.

17. Postler S. and Ghosh S.: Bridging the gap: a regulator of NF- $x$ B linking inflammation and cancer. J. Oral Bio sci. 2015; 57: 143-147.

18. DiDonato J., Mercurio F. and Karin M.: NF- $x$ B and the link between inflammation and cancer. Immunol. Rev. 2012; 246: 379-400.

19. Aggarwal B. and Sung B.:NF- $x$ B in cancer: a matter of life and death. Canc. Discov. 2011:1: 469-471

20. Nakayama H., Ikebe T., Beppu M. and Shirasuna K.: High expression levels of nuclear factor $\varkappa \mathrm{B}$ I $\varkappa \mathrm{B}$ kinase $\alpha$ and Akt kinase in squamous cell carcinoma of the oral cavity. Cancer 2001; 92: 3037-3044.

21. Vainio H. and Weiderpass E.: Fruit and vegetables in cancer prevention. Nutr. Canc. 2006;54:11- 42.

22. Cerda B. Tomas-Barberan F. and Espin J.:Metabolism of antioxidant and chemopreventive ellagitannins from strawberries, raspberries, walnuts, and oak-aged wine in humans: identification of biomarkers and individual variability. J. Agric. Food Chem. 2005;53:227-235.

23. Aaby K., Skrede G. and Wrolstad R.: Phenolic composition and antioxidant activities in flesh and achenes of strawberries (Fragaria ananassa). J. Agric. Food Chem. 2005; 53:4032- 4040.

24. Zhanga Z., Knoblocha T., Seamonc L., Stonerd G., Cohnb D., Paskettb E., Fowlerb J. and Weghors C.: A black raspberry extract inhibits proliferation and regulates apoptosis in cervical cancer cells. Gynecol. Oncol. 2011;123:401- 406

25. Seeram, N., Adams L., Zhang y., Lee R.,Sand D., Scheuller H. and Heber D.: Blackberry, black raspberry, blueberry, cranberry, red raspberry. and strawberry extracts inhibit growth and stimulate apoptosis of human cancer cells in vitro. J. Agric. Food Chem.2006; 54: 9329-9339.

26. Han,C., Ding H., Casto B., Stoner G. and D'Ambrosio S.: Inhibition of the growth of premalignant and malignant human oral cell lines by extracts and components of black raspberries. Nutr. Canc. 2005;51, 207-217.

27. Ceci C., Lacal P., Tentori L., Gabriella De Martino M., Miano R. and Graziani G.: Experimental Evidence of the Antitumor, Antimetastatic and Antiangiogenic Activity of Ellagic Acid. Nutrients 2018, 10,1-23. 
28. Nicholson D.: Caspase structure, proteolytic substrates and function during apoptotic cell death. Cell Death Diff. 1999;6:1042-1048.

29. Zikri N., Riedl K.,Wang L., Lechner J.,Schwartz S. and Stone G.: Black Raspberry Components Inhibit Proliferation, Induce Apoptosis and Modulate Gene Expression in Rat Esophageal Epithelial Cells. Nutr. Canc.2009 ; 61: 816-826.

30. Nguyen T., Tran E., Nguyen., Pt D., Huynh T. and Huynh H.: The role of activated MEK-ERK pathway in quercetininduced growth inhibition and apoptosis in A549 lung cancer cells. Carcinogenesis 2004; 25:647-659.

31. Hsia T., Kuo H., Chao P., Chou C., Wei Y. and Chung $\mathrm{J}$.: Inhibition of lung cancer cell growth by querceitn glucuronides via G2/M arrest and induction of apoptosis. Drug Metab. Dispos. 2006; 34:296-304.

32. Julien S., Puig I., Caretti E., Bonaventure J., Nelles L., Van Roy Y., Dargemont C., De Herreros A., Bellacosa A. and
Larue L.: Activation of NF- $x$ B by Akt upregulates Snail expression and induces epithelium mesenchyme transition. Oncogene 2007; 26:7445-7456.

33. Ikebe T., Takeuchi H., Jimi E., Beppu M., Shinohara M. and Shirasuna K.: Involvement of proteasomes in migration and matrix metalloproteinase-9 production of oral squamous cell carcinoma Int. J. Canc. 1998; 77: 578-585.

34. Madhusoodhanan R', Natarajan M., Singh J., Jamgade A., Awasthi V., Anant S., Herman T. and Aravindan N.: Effect of black raspberry extract in inhibiting NFkappa B dependent radioprotection in human breast cancer cells. Nutr. Canc.2010;62: 93-104.

35. Hecht S., Huang C., Stoner G., Li J., Kenney P., Sturla S. and Carmella S.: Identification of cyanidin glycosidesas constituents of freeze-dried black raspberries which inhibit anti-benzo(a)pyrene-7,8diol-9,10-epoxide induced NFjB and AP-1 activity. Carcinogenesis 2006; 27:1617-1626. 